\title{
Information model of project management process of creating a technology transfer office
}

\author{
D. Tymchenko, N. Korogod, T. Novorodovska
}

National Metallurgical Academy of Ukraine, Dnipro, Ukraine
Corresponding author. E-mail: dariatymchenko1@gmail.com

Paper received 29.08.20; Accepted for publication 18.09.20.

\section{https://doi.org/10.31174/SEND-NT2020-238VIII29-15}

\begin{abstract}
This article proposes an information model of the project management process of creating a technology transfer office (hereinafter - TTO), which will increase the efficiency of project management and provide efficient and operative communication between project stakeholders. The application of this information model will allow any higher education institution (hereinafter - HEI) to effectively exchange information flows between stakeholders at each stage of the project, which is the key to successful project implementation and creating an efficient project product on time and within budget.

Keywords: technology transfer office; technology transfer office creation; information model of project of creating a technology transfer office; stakeholders of project of creating a technology transfer office.
\end{abstract}

Introduction. The creation of TTO is an urgent task for HEI because the vector of Ukrainian policy is aimed at building an innovative ecosystem [1]. However, the authors' analysis of domestic and foreign sources showed that this issue has not been studied taking into account the project approach [2]. At the same time, the creation of TTO is a project itself, and therefore the application of project management methodology will allow to implement this project as effectively as possible. In the implementation of any project an important role is played by considering the interests of stakeholders and providing efficient communication between them, which is the main task of the information model proposed in the article.

Review of publications on the topic. TTO is in fact a project management office (hereinafter - PMO) in the field of technology transfer. In Project management body of knowledge (PMBOK) the PMO is defined as a management structure that standardizes project management processes and facilitates the exchange of resources, methodologies, tools and techniques [3]. P2M [4] defines the task of PMO as following: it coordinates the appointment of professionals in all project teams, provides line project teams with project management technology and related services.

The issue of the functioning of project offices has been studied by many foreign scientists, among them - I. Kendall and S. Rollins [5], Trukhanovsky O.M. [6], even the issue of the organization of the PMO was studied. Domestic scientists define the concept of PMO [7], identify functions and types [8]. However, the issue of creating a PMO (TTO) in HEI has its own characteristics, and therefore requires more in-depth research.

By TTO the authors understand the specific organizational structure which is engaged in management of projects and portfolios of projects of technology transfer, applying the project approach in the activity, within uniform information and communication system of the organization.

A technology transfer project is a sequence of managed measures to coordinate human, material and information resources throughout the technology life cycle in order to transfer and implement the results of research and development of HEI in the field of business to create an innovative product based on them.
The aim of this study is to increase the efficiency of project management of TTO creation in HEI and to provide efficient and operative communication between project stakeholders by building an information model of the project management process.

Materials and methods. During the study, a system approach and methodology of graphic simulation of information systems were used. In a system approach, the object of study is a system, a whole, a set of elements interconnected and interacting with each other, which is characterized by the presence of integrative qualities that cannot be reduced to the sum of the qualities of its parts [9; $10]$.

Within the system approach the problem is solved systematically by means of consideration of all elements of the project and their general optimization [11].

A system approach is the basis for building models and management methods that clearly define the goals and measures to provide the achievement of the project goal [9]. This approach is proposed to be used at the stage of project initialization in forecasting product performance indicators - feasibility study of expediency of product creation in combination with methods of system modeling [12].

The construction of the information model was also based on the methodology of graphic simulation of information systems - a special construction technology: data flow diagrams (DFD). The information model of the system in DFD is a data flow that is graphically represented using a certain notations system: external entity (terminator); process; subsystem or system; data storage or storage; data flow [13; 14].

Results and discussion. Any project management process involves managing project data flows, managing project stakeholders and communications. It is the effectiveness of the interaction of project stakeholders that directly determines whether the project product should be created efficiently, on time and within the planned budget. The introduction, processing and exchange of project data between stakeholders plays an important role in the project management process.

The project management process for the creation of TTO in HEI also involves the effective management of project data flows, stakeholders and communications. Stakeholders of TTO project in HEI: initiator, manager, project team, supervisor, customer, owner, investors, 
competitors, authorities, public community, suppliers and contractors, consumers.

In order to increase the efficiency of project management of TTO in HEI and provide efficient and operative communication between project stakeholders, the author proposed an information model in Fig. 1.

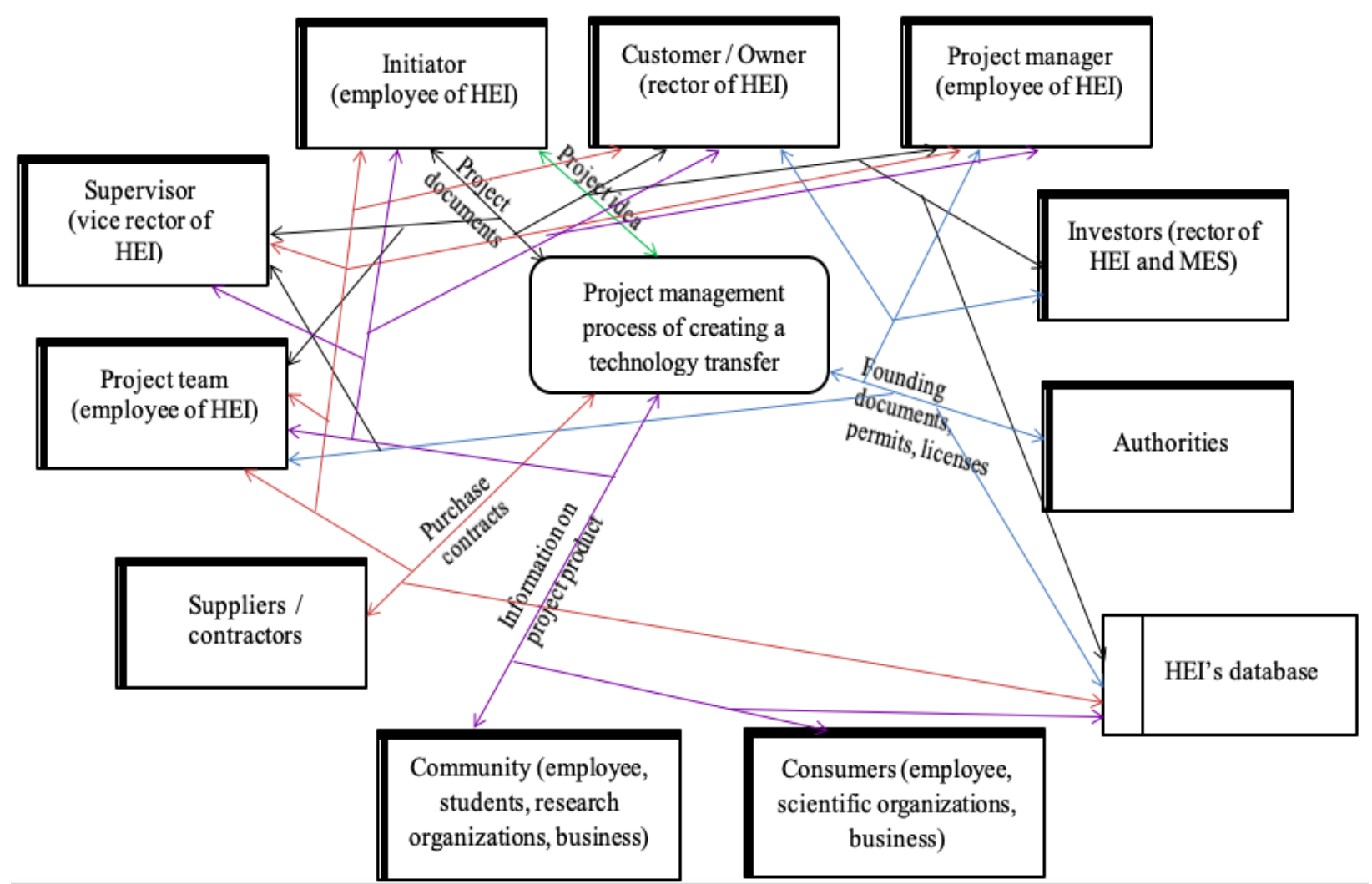

Fig.1. Information model of TTO project management process in HEI (DFD notation, context diagram) [Built by the author]

Due to the proposed in Fig. 1 information model, it could be traced how stakeholders interact in the process of managing the project of creating TTO in HEI and using what exactly documents. Information flows of the project management process of TTO creation in HEI are given in table 1 .

Table 1. Information flows between stakeholders in the process of project management of creating TTO in HEI

\begin{tabular}{|l|l|l|l|}
\hline № & Exchanged information & \multicolumn{1}{|c|}{ Stakeholders that provide information } & \multicolumn{1}{|c|}{ Stakeholders that receive information } \\
\hline 1 & Project idea & Initiator & Customer, manager, supervisor, investors \\
\hline 2 & Project documents & $\begin{array}{l}\text { Initiator, team, supervisor, manager, cus- } \\
\text { tomer, owner }\end{array}$ & $\begin{array}{l}\text { Team, supervisor, manager, customer, owner, } \\
\text { investors }\end{array}$ \\
\hline 3 & $\begin{array}{l}\text { Founding documents, } \\
\text { permits, licenses }\end{array}$ & Authorities & $\begin{array}{l}\text { Project team, manager, customer, owner, su- } \\
\text { pervisor }\end{array}$ \\
\hline 4 & Purchase contracts & Suppliers and contractors & Team, supervisor, manager, customer, owner \\
\hline 5 & $\begin{array}{l}\text { Information on project } \\
\text { product }\end{array}$ & $\begin{array}{l}\text { In the process, the community receives in- } \\
\text { formation about the project product from } \\
\text { the customer, supervisor or manager }\end{array}$ & $\begin{array}{l}\text { Customer, owner, manager, supervisor, team, } \\
\text { community, consumers, authorities }\end{array}$ \\
\hline
\end{tabular}

Table 1 allows to track the information exchanged by stakeholders of the project of TTO creation in HEI, as well as directly the stakeholders who provide and receive information. All information is stored in HEI's database as shown in Fig. 1.

The process of project management of TTO creation in HEI involves the several stages including: project initialization, planning, implementation control, completion and final analysis of the project. At each of these stages, there are certain information flows between different stakeholders. In order to increase the efficiency of project management, the creation of TTO in HEI at each of the above-mentioned stages and to provide efficient and operative communication between project stakeholders at the appropriate stages, the information model on DFD notation in the form of the diagram of 1 level is suggested by the authors as shown in Fig. 2. 


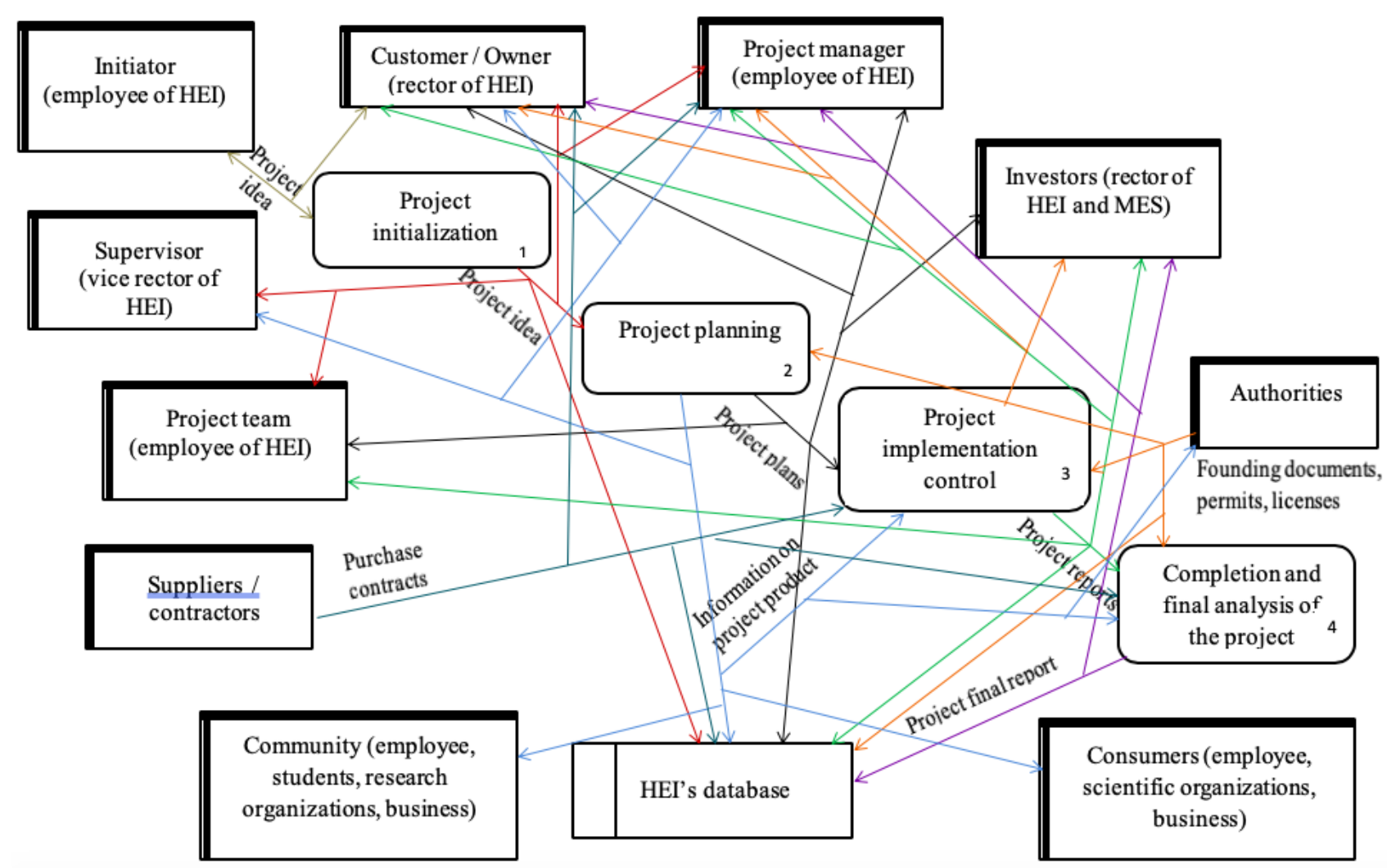

Fig. 2. Information model of the project management process of TTO creation in HEI (DFD notation, level 1 diagram) [Built by the author]

Due to the proposed in Fig. 2 information model the as well as using which documents. Information flows of interaction of stakeholders could be traced at each stage of each stage of the project management process for the TTO the project management process of TTO creation in HEI, creation in HEI are shown in table 2.

Table 2. Information flows between stakeholders at each stage of project management process of TTO creation in HEI

\begin{tabular}{|c|c|c|c|}
\hline № & Exchanged information & Stakeholders that provide information & Stakeholders that receive information \\
\hline \multicolumn{4}{|c|}{ 1. Project initialization } \\
\hline 1.1 & Project idea & Initiator & Customer \\
\hline 1.2 & Project charter & $\begin{array}{l}\text { Manager, supervisor, team, customer, } \\
\text { owner }\end{array}$ & $\begin{array}{l}\text { Team, supervisor, manager, customer, owner, in- } \\
\text { vestors }\end{array}$ \\
\hline \multicolumn{4}{|c|}{ 2. Project planning } \\
\hline 2.1 & Project charter & $\begin{array}{l}\text { Manager, supervisor, team, customer, } \\
\text { owner }\end{array}$ & Team, manager, customer, owner, supervisor \\
\hline 2.2 & Project plans & $\begin{array}{l}\text { Manager, supervisor, team, customer, } \\
\text { owner, investor }\end{array}$ & Team, manager, customer, owner, investors \\
\hline 2.3 & $\begin{array}{l}\text { Founding documents, } \\
\text { permits, licenses }\end{array}$ & Authorities & Manager, customer, owner, investors, authorities \\
\hline 2.4 & $\begin{array}{l}\text { Information on project prod- } \\
\text { uct }\end{array}$ & Manager, supervisor or customer & $\begin{array}{l}\text { Supervisor, manager, customer, owner, commu- } \\
\text { nity, consumers }\end{array}$ \\
\hline \multicolumn{4}{|c|}{ 3. Project implementation control } \\
\hline 3.1 & Project plans & Manager & Team, manager, customer, owner, investors \\
\hline 3.2 & Purchase contracts & Suppliers and contractors & Customer, manager \\
\hline 3.3 & $\begin{array}{l}\text { Information on project prod- } \\
\text { uct }\end{array}$ & Manager & $\begin{array}{l}\text { Supervisor, manager, customer, owner, commu- } \\
\text { nity, consumers }\end{array}$ \\
\hline 3.4 & $\begin{array}{l}\text { Founding documents, } \\
\text { permits, licenses }\end{array}$ & Authorities & Manager, customer, owner, investors, authorities \\
\hline 3.5 & Project reports & Team & Manager, supervisor, customer, owner, investor \\
\hline \multicolumn{4}{|c|}{ 4. Completion and final analysis of the project } \\
\hline 4.1 & Purchase contracts & Suppliers and contractors & Team, supervisor, manager, customer, owner \\
\hline 4.2 & $\begin{array}{l}\text { Founding documents, } \\
\text { permits, licenses }\end{array}$ & Authorities & Manager, customer, owner, supervisor, team \\
\hline 4.3 & Project final report & Team & Manager, supervisor, customer, owner, investors \\
\hline 4.4 & $\begin{array}{l}\text { Information on project prod- } \\
\text { uct }\end{array}$ & Manager, supervisor or customer & $\begin{array}{l}\text { Customer, owner, manager, supervisor, team, } \\
\text { community, consumers }\end{array}$ \\
\hline
\end{tabular}


Thus, the information model of project management process of TTO creation in HEI proposed in this article allows to identify information flows between project stakeholders and increase the communication efficiency that will increase the efficiency of the project as a whole and allow to create a project product efficiently, on time and within budget.

\section{REFERENCES}

1. Tymchenko, D.O. (2020) 'Problems of creating an innovative ecosystem in Ukraine', Bulletin of NTU" KhPI". Series: Strategic management, portfolio, program and project management, vol. 2, DOI: 10.20998/2413-3000.2020.2.8.

2. Tymchenko, D. (2020) 'Modern approaches to project management creation of project offices in higher education institutions', Management of Development of Complex Systems, issue 42, pp. 28-38.

3. Project Management Body of Knowledge (PMBOK Guide): Project Management Institute: Sixth Edition (2017), 726 p.

4. P2M: Guide to managing innovative projects and programs of enterprises. Japanese Project Management Association (PMAJ). Translation, ed. Bushuyev, S.D (2009), K.: Nauk. svit. $155 \mathrm{p}$.

5. Kendall, I., and Rollins, K. (2004) 'Modern Methods for Project Portfolio Management and Project Management Office: Maximizing ROI', Trans. from English, Moscow, ZAO "PMSOFT", $338 \mathrm{p}$.

6. Trukhanovsky, O.M. (2012) 'Organization of a project management office in order to increase the effectiveness of innovation and investment projects', Abstract. diss. for the degree of candidate of economic sciences, specialty - 08.00.05 - Economics and National Economy Management. Moscow: FSBEI HPE "STATE UNIVERSITY OF MANAGEMENT", 23 p., https://guu.ru/files/referate/truhanovsky.pdf

7. Morozov, V.V., and Chernenko, Yu.V. (2012) 'Conceptual model of organizational management system in the implementation of the strategy of innovative development of project-oriented organizations', IX International Conference "Project Management in Society Development". Management of programs and projects in the global financial crisis, pp.156157

8. Bushuyev, S.D., Bushuyeva, N.S., and Shorop, D.I. (2004) 'Project office as a methodology of multi-project management', Project management and production development: Zb.nauk.pr. Luhansk: published by SNU. V. Dalya, https://cyberleninka.ru/article/n/proektniy-ofis-yakmetodologiya-multiproektnogo-upravlinnya/viewer

9. Kuzminska, Yu. (2019) 'Models and methods of forming teams of educational projects for advanced training'. Thesis for the degree of Candidate of Technical Sciences on the specialty 05.13.22. "Project and program management" (12 Information Technology, 126 - Information Systems and Technologies). Lviv State University of Life Safety of the State Emergency Service of Ukraine, $221 \mathrm{p}$.

10. Zemlyankin, A.I., and Pidorycheva, I.Yu. (2009) 'Conceptual approach to the integration of science, higher education and industry'. Strategy and mechanisms for regulating industrial development: Zb. nauk. pr. Donetsk: IEP NASU. pp. 87-100. URL:

http://dspace.nbuv.gov.ua/bitstream/handle/123456789/39617 /08-Zemliankin.pdf? sequence $=1$

11. Lozovskii, and O.M., Kashina, O.O. (2014) 'Features of using a systems approach in project management at the enterprise'. Bulletin of Khmelnytsky National University, № 3, vol. 2. pp. 51-54.

URL: file://Users/dariatymchenko/Downloads/Vchnu_ekon_2014_ 3(2)_12.pdf

12. Sydorchiuk, O.V., Ratushnii, R.T., Sydorchiuk O.O., and Demediuk M.A. (2011) 'System approach to project and program management: definition of principles'. Eastern European Journal of Advanced Technology. № 5 (49), vol. 1. pp. 30-32. URL: http://www.irbis-nbuv.gov.ua/cgibin/irbis_nbuv/cgiirbis_64.exe?I21DBN=LINK\&P21DBN=U $\mathrm{JRN} \& Z 21 \mathrm{ID}=\& \mathrm{~S} 21 \mathrm{REF}=10 \& \mathrm{~S} 21 \mathrm{CNR}=20 \& \mathrm{~S} 21 \mathrm{STN}=1 \& \mathrm{~S} 2$ $1 \mathrm{FMT}=\mathrm{ASP}$ meta\&C $21 \mathrm{COM}=\mathrm{S} \& 2 \quad \mathrm{~S} 21 \mathrm{P} 03=\mathrm{FILA}=\& 2 \quad \mathrm{~S} 21$ STR=Vejpte_2011_1(5)_10

13. Cepeda Guaman, D.F. (2020) 'Risk management of stakeholders in organizational projects in the sphere of maintenance of aircrafts within the framework of the behavioral economy'. Thesis for the degree of Candidate of Technical Sciences on the specialty 05.13.22 «Project and program management» (12 - Information Technology, 126 Information Systems and Technologies). Lviv State University of Life Safety of the State Emergency Service of Ukraine, 186 p.

14. Danchenko, O.B. (2017) 'Practical aspects of business process reengineering', University of Economics and Law «KROK», Kyiv, 238 p. 